\title{
UMRAH TRENDS: \\ QUESTION BETWEEN FOLLOWING SUNNA AND SPIRITUAL TOURISM
}

\author{
Subkhani Kusuma Dewi* \\ UIN Sunan Kalijaga, Indonesia \\ e-mail: kusummadewi@gmail.com
}

\begin{abstract}
Spiritual tourism is not a new phenomenon. It has been studied from tourism perspectives. However, when the tourism became a global trend of religious expression, the perspective of the sociology of religion get its place. In Indonesia, although Muslims perform hajj, visiting and praying in famous cemeteries (ziyāra), and umrah are also included into this trip. Spiritual tourism at the same time has affected and has been affected by religious views, including the understanding of what is referred to as Sunna. This condition has enfolded how umrah is performed as a social trend today. By looking at the concept of spiritual tourism from sociological perspective, this paper further utilizes umrah and hajj travel agencies' angle in seeing of what is so called Sunna, and how it has influenced the performance of umrah. The study demonstrates the important role of travel agencies in forming a strategy to attract pilgrims by two steps: by binding umrah as a recreation/travel and placing it as a modern distinctive way of worship.
\end{abstract}

Keywords: Sunna, Umrah, ziyāra, Spiritual Tourism

DOI: http://dx.doi.org/ 10.20414/ujis.v21i2.318

* A deep gratitude is devoted to Shofaul Jannah and husband who assisted me during observation of this research in Yogyakarya, Agencies members and muțawwif; Bayu, Ulin, Rimaya, Ustadz Yusuf for their remarkable information and insight. Dr. Abdul Mustaqim's insight and input during researcher's presentation before Faculty's memberss is deeply appreciated. Last but not least, Dwi Retno Widiyanti for her though effort in editing the draft in English version. 


\section{Umrah and Hajj as a Social Phenomenon}

The existence of umrah in Islamic rituals is important. If it is part of the pilgrimage, the hajj will not be valid if umrah is not included therein. ${ }^{1}$ When it is done independently, umrah is sunna (nonobligatory rituals). However, for Muslims, umrah is a favorable rituals not only because they want to get a chance to worship Allah, but also because of umrah is an incredible journey. Umrah consists of a multi-dimensional worship encompassed the spiritual, material, as well as physical dimensions.

"Umrah in terminology means a visit; visit the Ka'aba and a visit that demands spiritual preparation and a strong body, because Umrah is not an ordinary visit to the Ka'aba." 2

Umrah and hajj trips include 'ubüdiyyah dimension (worship) and insāiyyah (humanity), where Muslims practice what the Prophet Muhammad and his ancestor, Prophet Ibrahim had done. Therefore umrah is a kind of pilgrimage, and not only a physical pleasurable travel. It involves self-reflection through a special intention for worship, a series of rituals that are believed to be exemplary of the sunna of the Prophet.

In terms of economic capability umrah and hajj are also interesting. Ideally Islam has made hajj compulsory for those who can afford it, but the fact is that hajj and umrah are not solely performed by the wealthy Muslims. This is because the ideal and essence of hajj and umrah are the fulfillment of worship, happiness of the hearts $(f a l \bar{a} h)$ as part of the ultimate goal in life. Happiness could not just be measured through economic criteria, but is a thread of courage and can only be perceived in an inner and spiritual fulfillment. ${ }^{3}$

In his study "The image of Hajj in Media Construction", Soehadha categorized three variants of research on the pilgrimage

${ }^{1}$ On a comprehensive recent study on the pilgrimage in Islam, see Eric Tagliacozzo and M. Toorawa Toorawa, eds., The Hajj: Pligrimage in Islam (New York: Cambridge University Press, 2016).

2 "Bimbingan Manasik Haji" (Departemen Agama Republik Indonesia, 2003), 3.

${ }^{3}$ Sucipto, "Umrah sebagai Gaya Hidup, Eksistensi Diri dan Komoditas Industri: Menyaksikan Perubahan Keagamaan Warga Kota," Jurnal Kontekstualita 28, no. 1 (2013): 21. 
that has been done in Indonesia; namely the historical aspect, the theological aspect, and economic aspects. Historically there were several scientific works on Islamic pilgrimage (hajj) of Muslim in Indonesia. To mention some is a prominent writing done by Snouck Hugronje entitled "Het Mekkaansche feest" (Feast Society Mecca, 1879) during the colonial period. Another example is Martin Van Bruinessen's work that elaborated and showed the dynamic of motivation performed by Muslim communities in hajj traveling to Mecca. ${ }^{4}$ A relatively recent published work of Henri Charmbert-Loir (2013) which has elaborated extensive historical records (1482-1964) of Indonesian Muslims' pilgrimage while at the same time has indicated the huge numbers of pilgrims from Indonesia up to the 2000s era.

In the other side, sociological and anthropological research about the hajj has grown widespread. Willam R. Roff focused on the phenomenological account of hajj as a ritual. By using rite de passage and liminality theory, he concluded that the criteria for hajj al-mabrür (accepted hajj) is a socially traversed during the hajj processes from depart to return home, where one started to bring several changes within spiritual scheme in order to possess a better personality. Meanwhile anthropological studies carried out by Muslim Abdurrahman in the New Order period show hajj-plus models as a social phenomenon that causing resentment toward Indonesian society, to whom it describes a glamorous side of the middle-class Muslim groups. Following Abdurrahman, the studies on hajj and umrah often repeat social theories which lead to the formation of self-identity factors, where Muslims in Indonesia responded to the growing strength and proposition process of secularization in the global world. ${ }^{5}$

${ }^{4}$ The inspiration had expanded from studying Islamic knowledge, following the mission of Islamic teaching and dakwah (along with the spread of Islam to the Asia continental from the Neo-Sufism's path), up to gaining the support for fighting against colonialism, as well as to enculturating sufi path of into a more local expressions. Martin van Bruinessen, "Mencari Ilmu dan Pahala di Tanah Suci: Orang Nusanta ra Naik Haji (Seeking Knowledge and Merit: Indonesians on the Hajj)," Jurnal Ulumul Qur'an 2, no. 5 (1990): 42-49.

${ }^{5}$ Sucipto, “Umrah sebagai Gaya," 23. 
On the other side, economic studies show that political management of hajj and umrah in Indonesia was so often marked by increasing demand for a better service need of hajj. At times, it was also severely marked with corruption affairs, which led to even growing public's attention for more effective and accountable process. Political issues of hajj management in Indonesia is also demonstrated by long term negotiation process (the Indonesian government) in obtaining privileges for both quotas as well the services for Indonesia's pilgrims. ${ }^{6}$

In addition, the economic studies on the hajj rituals focused on the economic ability of the pilgrims have been made by Zamakhsyari Dhofier, who stated that although the hajj were dominated by Muslims from a higher economic level, but Muslims of lower economic level also strive to finance their pilgrimage visit. This was an excuse for hajj as an 'ibādah symbolizes highest spiritual attainment for Muslims. ${ }^{7}$

In addition to the latest work, economic studies generally dominated by a description of the hajj management policy in Indonesia that can never be separated from the international policy of the Government of Saudi Arabia on the hajj. Since 2013, the Saudi government has reduced by $20 \%$ of the world's quota of pilgrims since the government focused on improvements as well construction both Haramayn areas and facilities. ${ }^{8}$

From various studies above it can be specified that the importance of hajj's aspects as fundamental worship in Islam was not only came from a theological perspective. It complexities of management and social impact rise a very modern expression of 'ibādah. So that, hajj, today has also formed a very important ziya rah to Mecca, that it is umrah. The spiritual trip that now has

${ }^{6}$ See Tim Lindsey, "Monopolising Is lam: The Indonesian Ulama Council and the State Regulation of 'the Islamic Economy,'" Bulletin of Indonesian Islamic Studies 48, no. 2 (2012): 253-274.

7 Zamakhsyari Dhofier, “Dampak Ekonomi Haji di Indonesia," Prisma XIII, no. 4 (April 1984).

${ }^{8}$ Indonesian pilgrims quota which was originally supposed to amount to 211,000 pilgrims has been abated be 168,000 pilgrims. See "Keputusan Menteri Agama RI Nomor 210 Tahun 2016 Tentang Penetapan Kuota Haji Tahun 1437 H/ 2016 M," May 10, 2016, https://haji.kemenag.go.id/v3/content/ke putusan-menteria gama-ri-nomor-210-tahun-2016-tentang-penetapan-kuota-haji-tahun. 
been conditioned by both religious discourse as well as global tourism as an alternative of hajj.

\section{Umrah as Part of Global Tourism Trends}

Globally, it can be said that the Saudi Arabia's policy to gain a gigantic improvements in Haramain is a vivid impact of global tourism trends. 'Ala al-Harmaneh shows that since 2003/2004 the Saudi Arabia and the Middle East countries have presented a massive global tourism programs, as part of September $11 \mathrm{impact}$ toward tourism. Opposing to the stereotype of that tragedy and rejecting the common assum ption that Muslims (including Muslim countries) is identical with terrorism, Middle East countries made a huge promotion on safety and comfort for tourists to travel to Muslim countries. Saudi Arabia was one of the countries that participated on this trend. A rich country and a very important travel destination for Muslims around the world, Saudi Arabia has now intended to widen the variety of trip programs that are based on a new interpretation on the hajj and tourism destination. It was the first time during the history that Saudi Arabia promoted a "Summer Umrah", and the huge tourism exhibition on "Hajj and Umrah Exhibition" in Dubai in 2005. This program was also attended by other Arab countries, such as Jordania and Egypt to promote "Islamic Tourism" around the world. Iraq (at that time) had also promoted Najaf and Karbala as a safe and comfort sacred sites to visit. ${ }^{9}$

Amid growing global tourism in Muslim countries as well as the policies of both countries (Indonesia and the Government of Saudi Arabia), the Indonesian Muslim public interest toward umrah expanded increasingly. It was hand in hand with the increased market share of the tourism industry of this type, as well the significant number of umrah services and manufactures. While at the same time lots of critics toward the hajj directorate of Ministry of Religious Affairs to manage the hajj and umrah in a

\footnotetext{
${ }^{9}$ Ala al-Harmaneh, "New Tourism Trends in Arab World," Islamic Tourism, no. 16 (April 2005); See also Marjo Buitelaar, "Mecca as the Centre of Globalization: The Hajj Today," in Hajj: Global Interractions Trough Pilgrimage, by Luitgard Mals and Marjo Buitelaar (Leiden: Sidestone Press, 2015).
} 
more transparent way heighten public demand for a new era of professionalism for hajj and umrah management in Indonesia.

Following this, umrah is not only a matter of 'ubüdiyyah. When entering the world of professional industry, umrah became a traded commodity. At the same time, the management of umrah services involves many aspects and strategies for umrah businesses. Umrah agencies attempt to increase services and conditions to seek customers. The existence of the popular Muslim artists and preachers help market agencies' products. Networking business also penetrated umrah services industry as a palpable approach, where it can be a possible chance for every Muslim (whether they have enough money or not) to perform umrah to Haramayn land. This case could not be set apart from the role of electronic media such as commercials, sinetrons (a serial drama on TV), as well film in the cinema, to be part of an industrious marketing tool for this promising business. ${ }^{10}$

The strategy and the promotion of the business have successfully changed the images about hajj and/or umrah. It was in the era of Martin Van Bruinessen, Snouck Hurgonje, as well as Henri Chambert-Loir research where hajj was identified as an uneasy ritual, take a deadly risk such as timely extensive journey, separation from the family, as well as a jihad to gain more religious knowledge: but now hajj and umrah are rituals which are identical with achievable journey, full of fun, distinctive attires

${ }^{10}$ The TV series such as "Tukang Bubur Naik Haji” in RCTI. The rise of Islamic Film at the beginning of the millennium also helped bring depiction of Hajj and Umrah, such as "Emak Ingin Naik Haji" (2010), "Dibawah Lindungan Ka'bah" (2012), “Haji Backpacker" (2014), etc. Film and sinte ron This gave rise to the impression that the Hajj and Umrah is an everyday behavior (from the original only apply once a year, namely in the months of Hajj), then also presents images of land Haramain is no longer far away, but close to the heart and mind the devotees. Thus, the electronic media also indirectly make promotion of Hajj and Umrah, with how present directly in the middle of everyday audience. Moh. Soehadha, "Citra Haji dalam Konstruksi Media," in Cultural Studies di PTAI Teori dan Praktik, vol. 1, Bunga Rampai (Yogyakarta: Label, 2015), 158-174; For more information, please read Greg Fealy and Sally White, "Mengonsumsi Islam: Agama yang Dijadikan Jualan dan Kesalehan yang Diidam-idamkan di Indonesia," in Ustadz Seleb Bisnis Moral dan Fatwa Online; Ragam Ekspresi Islam Indonesia Kontemporer, translated from Expressing Islam: Religious Life and Politics in Indonesia (Jakarta: Komunitas Bambu, 2012), 26-33. 
and meals, comfortable activities. Close to the impression of an easy, fun, nice facility, accompanied with their piety idols from artists or famous figures, require a sort and effective time, and to such a degree, the pilgrims may get an extra business rewards. Todays traveling for Muslims may not be separated from spiritual activity. ${ }^{11}$

Those contemporary conditions help agencies to pay a deeper attention to arguments and classical resources of Islamic law as part of the primary reference in running their business services, so it will make the non-obligatory pilgrimage of umrah acceptable for either Islamic teaching as well as more modern adaptation. This is in line with the latest research on tourism which categorizes the type of tourism activity as a spiritual tourism. This means the travel activities undertaken by certain religious groups based on the motivation to implement most of the religious teachings and is intended as a means to achieve a certain spiritual level. Although the theory of spiritual tourism is fairly new, practically the phenomenon is commonly sustained. ${ }^{12}$

Farooq Haq, et. al., citing Haq and Jackson, defines spiritual tourism as:

“...an important segment of a massive tourism industry catering to needs of spiritual tourists in particular and facing competition as well as problems of survivability with other segments of the tourism industry. ...; a spiritual tourist is someone who visits a specific place out of his/her usual environment, with the intention of spiritual meaning and/or growth, without overt religious compulsion, which could be religious, non-religious, sacred or experiential in nature, but within a Divine context, regardless of the main reason for travelling. ${ }^{13}$

${ }^{11}$ In this regard, Islamic teaching allows Muslims to gain with for a more popular expression of traveling, however it should always be followed by an intention to religious concept of safar or ziyārah that is clear in this regard. Tourism in Islam is perfectly acceptable, if the primacy and pre requisites a re met, even recommended to do so. Sucipto, "Umrah sebagai Gaya," 7-8.

12 Daniel H. Olsen and Dallen J. Timothy, Tourism, Religion and Spiritual Journeys, (London: Routledge, 2006), 1-3.

${ }^{13}$ Farooq Haq, Anita Medhekar, and Phil Bretherton, "Public and Private Partnership Approach for Applying The Tourism Marketing Mix to Spiritual Tourism," in Academic Conference on Intellectual Perspectives \& Multi-Disciplinary Foundations, ed. David King, vol. 8 (presented at the Intellectbase International Consortium, Las Vegas, NV, USA, 2009), 63-64. 
The Islamic spiritual tourism, then, is a type of leisure activities with the aim to meet the demands of self-development and spiritual power as a way to achieve an awareness of close relationship to Allah (taqarrub ilā Allāh). During the travel Muslims will have other meaningful activities that aim to achieve certain goals, of eliminating depression feeling, the achievement of mental health, broaden brotherhood relationship among Muslims, and certainly during the course of traveling they may rejuvenate a spiritual purpose as wisdom and lessons on various aspects of life. ${ }^{14}$

From those various practices in the field, Haq concluded that spiritual tourism committed by Muslims can be divided into three types, the first pilgrimage is hajj, a main pillar of Islam and became one fundamental worship in Islam, held in Mecca for a certain time, namely from 8 to 12 Dzulhijjah every year. Second is rihlah, namely a trip for a particular purpose, such as a trip to study, to trade, specific research or travel for treatment. The third activity is referred as a ziyārah, which Muslims travel for visiting the cemetery of Muslim prominent or sufi figures, as well as visiting mosques or schools to obtain knowledge. In addition to the hajj, the journey, either rihlah or ziyārah can be referred to as a spiritual tourism. ${ }^{15}$

It is with the growing consciousness of public piety both umrah and hajj became socially more prestigious journey. While at the same time the tourism industry became an influential area that penetrated the wishes of the people in enjoying this spiritual journey. So, umrah which is actually a form of ziyarah and perceived as sunna or non-obligatory, is now considered to be a demand (need, or almost became an obligation). If that so, what did the travel agencies say and approach toward customers? The rest of the paper would further examine -based on their perceptions toward sunna- how travel agencies' understand

${ }^{14}$ A. A. Mustafayeva et al., "Developing Islamic Tourism in Kazakhstan: A Result of a Religious Revival or a New Trend of Tourism," World Academy of Science, Engineering and Technology International Journal of Social, Behavioral, Educational, Economic, Business and Industrial Engineering 6, no. 11 (2012): 6.

${ }^{15}$ Farooq Haq and Ho Yin Wong, "Is Spiritual Tourism a New Strategy for Marketing Islam?," Journal of Islamic Marketing 1, no. 2 (2010): 136-148. 
Umrah? Since the paper focuses on the study of sunna and its practice in the community, then the sub-chapter would further discuss how Sunna as a body of knowledge understood by prominent figures of travel agencies then transformed into other forms of services in the context of spiritual tourism.

\section{The concept of Sunna and its implications for Umrah Services Today}

The rise of umrah today may be concluded as a reciprocal relationship between tourism policies and demand from pilgrims who base their understanding that umrah is a call, and yet expected ritual. This chapter attempts to place Umrah as part of the sunna al-șahabah that is understood both by the pilgrims and umrah travel agencies. So this chapter will begin from the Sunna of the Prophet as a body of knowledge and understanding of umrah agencies (muțawwif).

\section{Umrah as Part of Development of the Sunna}

Sunna for Muslims can be interpreted as practical norms drawn from utterances or actions preached by the Prophet Muhammad. Sunna can be referred to as a living practice. ${ }^{16}$ Slightly different from the traditions that are literary, sunna are reports of practices that has become a normative and practical principles for generations of Muslims. In Islam, it is certainly believed that the authority on sunna is elucidated by the Prophet

16 Rahman explored the idea of Abū Yūsuf and al-Awzā'î̀ (when both discussed about the practice of muslim Madinah in buying and selling slaves in the land of enemy) and concluded about scope of sunna as more progressive concept. On the one hand, al-Awzā'î preferred to say that sunna was vary (meaning as deeds and exemplary, include that of the companion of the prophet), but the most authoritative was sunna of the prophet, and should be a primary references for muslims. On the other hand, Abū Yūsuf, Rahman stated, preferred to note spesifically as sunna Nabi. Yet he mentione d since the re had been part of prophet's life and deeds that were prefe rably as an individual matter, so muslims should not explicate -what is called sunna- as a matter of literally totalitarian. Moreover, "when the situation so demands, the exception to the rule must be applied as a rule." Fazlur Rahman, "Sunna and Hadith," Journal Islamic Studies, Islamic Research Instit ute, International Islamic University, Islamabad 1, no. 2 (June 1962): 2-3. 
Muhammad and or of the early generations (salaf), i.e. the Companions of the Prophet.

"Quran always draw together the Prophet Muhammad when talking about the authority, and the Muslims are always commanded to obey Allah and to His Messenger. When the Prophet was still alive, he was the supervisor of religion and politics only for Muslims, either through the Koran and the sayings and deeds of his own". ${ }^{17}$

The above excerpt was a vivid expression of a Pakistani Muslim scholar, Fazlur Rahman, that Prophet Muhammad has been expressed as a representation of the authoritative source of sunna. For Rahman, the Sunna of the Prophet which is basically a set of exemplary conduct had been steered inherently by and during the revelation of the Qur'an. ${ }^{18}$ The supremacy of sunna -as a lively concept- functioned for bayān al-Qur'ān (explanation of the Qur'an) as well as tashri' (Islamic law), gradually brought into an istinba t $a l-h u k m$ (jurisprudence) at that time. These steps have been adapted to the communal necessities which vary up to now. Historically speaking, Rahman had mentioned that during its formation, sunna has a tendency to submissively control over Muslims' practice and prone to accommodate Muslims' forthcoming conditions. Later, this seemingly "umbrella" characteristic of sunna (based on daily practice) will be constantly interpreted and reformed by later generations (particularly groups

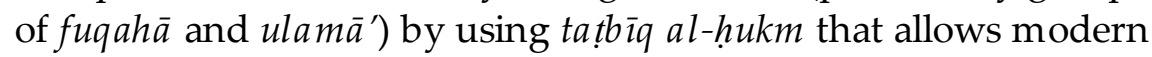
socio-cultural conditions tied in with the previous ideas. ${ }^{19}$

It is worth noting that sunna as a concept varies in definition as well as in scope. The various concern about sunna particularly

17 Mukhtar Lutfi, “Ijtihad Fazlur Rahman,” Al-Fikr 16, no. 2 (2012): 6.

${ }^{18}$ For further information, M. Guraya, "The Concept of Sunna in the Muwatta of Malik Bin Anas" (Ph.D. Dissertation, McGill University, 2015); M. Guraya, "The Concept of Sunna in the Muwatta of Malik Bin Anas," in The Concept of Sunna and Its Status in Islamic Law, ed. M. Guraya (New York: Palgrave, 2015), 2.

19 This exploratory points out Rahman's indistinctive idea between hadith and sunnah. While conceptually Rahman sees hadith as a literal-authority, he prefers to perceive the later as the very basic quality of hadith, reflecting main spirit of progressivity, contextual, and dynamic of sunna. Many have said this idea has put a liable study toward a wider scope of authority in Islam. Lutfi, "Ijtihad Fazlur Rahman," 7. 
rest references on a multifaceted Muslims' points of view in perceiving the position of Prophet Muhammad.20 This various ideas may spread from classical scholars to the contemporary ones. Even Orientalists, take an instance, believed that sunna, which was related to a living character and Prophet's exemplary, was relatively identical to ijma' (consensus of scholars), (including ijtih $\bar{a} d$ of the scholars of early Muslim generations, fuqahā'). ${ }^{21}$ In line to this idea, Duderija specified the perception of sunna in the first three centuries of Hijra as a set of general behavior concept as well as ethical model inferred from the life of first Muslim community. While the concept had not been systematized, sunna was significantly and progressively formulated either by oral transmission or the figure of prophet as a prototype of ideal life. Following Guraya's study about the concept of sunna in the era of Maliki, Duderija found that during this period the concept of sunna was barely perceived as "recognized Islamic religious norms and accepted standards of conduct derived from the religious and ethical principles introduced by the Prophet". While doing the same path and scrutinized its relevance for modern life, he proves this classical phase of sunna may be best expressed as "the non-hadith dependent concept of Sunna". 22

20 Following Suryadi in his study, this article differentiates various definitions of sunna from ahl al-ḥadìth, ahl al-uṣl, as well as ahl al-fiqh. Ahl alhadith concerned on the character and behavior of the prophet, stipulated sunna as verbally record of every deeds and sayings, silent permissions (or disapprovals), as well as characters of prophet. Second group of ulama who put their concern of prophet as a founding figure for the very principles of Islamic law, explain sunna as what had been proverb by the prophet, a part from alQur'an, either deeds, sayings, silent permissions (or disapprovals), or taqrïr, that may be based as a postulate for law. The last group of ulama' then express sunna every things and deeds was declared by prophet apart from what were categorized as wajib or farḍ. Suryadi and M. Mansur et al., "Dari Living Sunna ke Living Hadis," in Metodologi Penelitian Living Qur'an dan Hadis (Yogyakarta: TH Press, and Teras, 2007), 89-91.

${ }^{21}$ Ibid., 93.

${ }^{22}$ Further reviews are in Guraya, "The Concept of Sunna," 4; Adis Duderija, "Evolution on the Concept of Sunna during the First Four Generations of Muslims in Relation to the Development of the Concept of an Authentic Hadith as Based on Recent Western Scholarship," Journal of Arab Law Quarterly 26, no. 4 (January 2012): 393-437. 
Since Muslims community grew ever larger, widespread and diverse (after the death of Prophet Muhammad) the need for the initiation of the sunna's codification into a set of hadith had become very urgent. They felt the need for a very base of body of knowledge, as part of the need for the daily religious life's guidance, preferences of legal decisions, even considerations for Muslims' political deliberations. Since then, as a consequent of this changing, the sunna was often perceived as the hadith itself. Duderija, then, reflected to this period as the writing and codification of hadith which he described as "hadithification" of Sunna with various distinguishing characteristics compared to the previous period, among others are:

a. The continued growth and proliferation of hadith;

b. The increasing importance given to hadith at the cost of what he termed as non- hadith dependent concept of sunna that was prevalent in the first two centuries of Islam as mentioned above;

c. The articulation of non-verbally based aspects ${ }^{23}$ of sunna into individual, sound (sahìh) hadìth;

d. The increasing application of hadith to al-Qur'ān and sunna sciences such as jurisprudence (fiqh), Qur'ānic exegesis (tafsìr), legal hermeneutics (ușūl al-figh);

e. The development of hierarchical, legal hermeneutical models that were entirely textual-based (i.e. based on Qur'ān and hadith) and the marginalization of non-textual based of epistemological and methodological tools of sunna ( and Qur'ān) such as $r a^{\prime} y$ (reason-based opinion), ijtihād, as well as istihsān, and

f. The idea that Sunna (and the Qur'ān) are conceptually coterminous with certain ethical values or principles, such as justice or righteous conduct, including the expression Sunna al-'âdila that was employed by Muslims in the second century AH.

${ }^{23}$ Such as the idea that Sunna represented certain abstract ethico-religious principals and norms 
The sunna (and the Qur'an) is conceptually linked to the principles and ethical values, such as justice, righteous conduct, also including the expression of al-'adalah based on Sunna. According to Duderija, the idea has been widely practiced in both the first century of Muslim community. But today, hadith is often interpreted as a hard doctrine, regarded as the very standard rules that seemed to lose its openness to various aspects of the social situation; even regardless of the purpose of the prophet of a particular action (sabāb al-khușuss). Under these conditions sunna, certainly, has been perceived as a rigid system and likely executed as a solid cells of life. So, sunna only can be accessed through a codified hadith. ${ }^{24}$

\section{Sunna as the Guide and Travel Agen cies' Motivation}

In the condition where Muslims accessed hadith as the source for the righteous conduct, umrah is perceived in figh as a kind of non-obligatory pilgrimage for Muslims. In contrast to hajj, umrah, which is not done in a particular month, can be performed by Muslims repeatedly in accordance to their physical and financial ability.

Literally, the word umrah comes from the word I'timar means ziyārah, to travel for religious reason. Umrah includes activities such as religious visit to the Ka'ba and surround it by performing tawāaf, then $s \bar{a} ' i$ between șafā and marwāh, and lastly, ta hallul. Apart from hajj, there is no obligation to stay overnight at Arafah in umrah. Due to a series of umrah only take a small part of the Hajj's route then it is sometime called as a small hajj. Umrah can be performed at any time (except at those times been detested; the day of 'Arafäh, Nahar, and Tashrīq). In performing umrah, pilgrims must perform prerequisite of umrah (rukun) namely: 1. Wearing $i h r a \bar{m}$ attires (expressed as an intention to Allah for performing umrah) in Mìqāt; 2. Performing tawāf seven times; 3. Performing $s a^{\prime} i$ between the hill of $s f \bar{a}$ and marwāh; and 4. Having one's hair shaved (tahallul).

${ }_{24}$ Richard Bulliet, Islam the View from the Edge (New York: Columbia University Press, 1994), 3. 
Actually there is no rigid guidance about spiritual tourism in Islam. It is flexible because it is not required to meet a specific objective, but rather as an appeal that Muslims travel to various places in the world. The most important aspect in Islam about travel and leisure is a balance between the two aspects: the worldly and afterlife destination. ${ }^{25}$

This predominantly simple guidance for umrah entails a more flexible and timely activities attached to the 'ib $\bar{a} d a h$. In a morally articulation, Islam acknowledges Muslims to have a tadabbur (a lesson) during their travelling around the world. ${ }^{26}$ While at the same time, Islam recommends the traveling as a balanced activity between worldly leisure and ritual for their spiritual need. ${ }^{27}$

The ultimate consideration for spiritual journey shows the special treatment need to be accessed by Muslims. And this is recognized by many umrah travel agencies, shown by their amenities that are intangible such as holding series of gatherings for $d u^{\prime} \bar{a}^{\prime}$ and $d h i k r$ (chanting) before traveling. Further, these travel agencies take advantage of intensive meetings with the pilgrims such as mujāhadah, chanting during pregnancy, and so forth. So in terms of business, services to the customer are critical to the success of this kind of travel agency. From the description below clearly visible how the service providers, some of which is based on a certain understanding on the Sunna then practiced umrah pilgrimage as well as worship. Aspects of worship indicated by the understanding of the sunna (and more as figh), while from the aspect of pilgrimage is shown by the series of activities carried out either as a distinguishing identity as well as the answers to the spiritual needs of the pilgrims.

25 Siti Hasnah Hassan, Siti Rohaida Mohamed Zainal, and Osman Mohamed, "Determinants of Destination Knowledge Acquisition in Religious Tourism: Perspective of Umrah Travelers," International Journal of Marketing Studies 7, no. 3 (May 31, 2015): 2-3.

26 Muslims commonly understood one of weak hadith which stated that gaining knowle dge is a participatory action for every individual of Muslim. Also, it was assumed that the hadith recommend to have travelling as well as ziyāra.

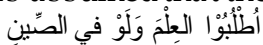

27 Hassan, Zainal, and Mohamed, “Determinants of Destination," 2-3. 
The Motivation of Travel Agencies as part of the perception of the Sunna of the Prophet

Since Muslim in Indonesia became more familiar with the leisurely of umrah so travel agencies have opportunity to offer various motivation, goal, and model. ${ }^{28}$ For example, Al Azhar Travel, in Solo, Central Java, stressed their objective to hold a Prophet Muhammad-based of umrah. The owner of Al Azhar acknowledged the existence of numerous travel agencies, either belong to or affiliated with any Muslim religious organization. But their services intensely offered for specific member of communities. In addition, Al Azhar saw the reality that Muslims, in their area today, facing various background; so they may offer umrah's services that recognize these varieties of need and demand. Those are ranges of social class background, affiliated religious organization, as well as their spiritual need. In doing so, mutawwif (travel guide bodies) in this travel agency have emphasized to serve rituals guided by sunnah of the Prophet Muhammad. Another goal of this agency was to facilitate and disseminate the idea to their prospective pilgrims that the most important part of this spiritual tourism is the worship and be grateful to Allah.

The other travel agency observed was ASBIHU Tour \& Travel, in Jakarta. It set up the goal of agency as an effort in keeping many umrah and hajj pilgrims in Indonesia to understand diversity of socio-religious background of worshipers in Mecca and Medina, thus they will find dissimilar madhāhib implemented during the rituals. Moreover, ASBIHU concerns more on the possible influence of Wahhabi's teaching that may promote prohibition against the existed cultural Muslim practices in their homeland. It is, then, necessary for ASBIHU Tour \& Travel to preach the rituals in accordance to sunni madhhab. ${ }^{29}$

${ }^{28}$ On the same issue in the Malaysian context, read Mohamed Battour et al., "Islamic Tourism: An Empirical Examination of Travel Motivation and Satisfaction in Malaysia," Current Issues in Tourism 20, no. 1 (January 2, 2017): 5067.

${ }^{29}$ Mustofa Aqil Siradj stated: “ASBIHU was established to maintain didirkan sudah tepat, untuk mempertahankan benteng aqidah jama'a NU's theological stance". Www.nuonline.com provides membuat the standard of $t$ manasik haji 
Unlike ASBIHU which emphasizes the strategic to maintain the theological view of the pilgrims, Travel Wisata Hati, Semarang established to present solutions and provide motivation of Muslims to go to Haramain, and provide them with both mental and spiritual assistance, so they will be confidently motivated to perform umrah:

"Wisa ta Hati emphasizes its role as counselor of worship, provide ass istance to pilgrims, in order to be able to develop themselves optimally to the way to find God, close to Allah, perform and do good deeds, loved the sunna, understand themselves, care about their surrounding, to overcome obstacles in order to determine a better future plans. Wisata Hati Travel, Semarang initially focusing attention on counseling activities. It was initially to pursue a rahmatan dakwah for the very need of ummah. So, umrah and hajj was one the very complex problem faced by ummah. There are lots of ummah who wished to perform the pilgrimage and Umrah, but could not afford the funds to carry out the practice. ${ }^{30}$

This kind of mission is in line to Zhafirah Tour and Travel in Jogjakarta. Umrah is a sunnah, non-obligatory worship but preferable to practice. So, it emphasizes the importance of glorifying Allah through prophetic sunnah. Therefore every Muslim should -at least once in his lifetime- to perform Umrah. Even, it is a mandatory for those who are able to afford needs for going to Mekkah and Madinah. ${ }^{31}$

dan umrah ritual practice according to Muslim Sunni jurists. Asbihu NU, "Profile Asosiasi Bina Haji dan Umrah Nahdlatul Ulama (ASBIHU-NU)," n.d., accessed January 9, 2017, http://wis a ta haji.com/profil-a sbihu-nu/.

${ }^{30}$ Yestik Arum, "Implementasi Actuating dalam Program Riyā ḍah Umroh dan Haji di Wisata Hati Semarang Tahun 2011" (Undergraduate Thesis, IAIN Walisongo, 2013), 48 Since 2011, this agency has merged to DaQu Travel, PT Al Amin Mulia Lestari, whom Ust. Yusuf Mansur, popular spiritual leader who focused his dakwah to emphasize the importance of sedekah (giving alms), become the Guru and supervisor of the agency. For more info, please check www.daqutravel.com (accessed January 8, 2017).

${ }^{31}$ Interview with Nuril Huda, mutawwif Zafira Tour and Travel Agency, Yogyakarta: February 17, 2016, 2:20 pm. I try to access the hadith mentioned by Huda. At least there are three major idea in accord to this issue. Imam Abu hanifah and Imam Malik stated that Umrah was basically a non-obligatory ritual/prayer in Islam. This idea was the most prominent idea. While Imam Syafi'i, commonly the most preferable fikh jurisprudential-school in Indonesia, umrah is a preferable but non-obligatory. However, the latest ide was the most popular among fikh ulama, since those of Hanafiyah and other small group of 


\section{Umrah: a trip to imitate the Sunna}

It is necessary to note that umrah was not only an ibadah done during the trip. In terms of preparation for the pre-departure, every travel agency promotes special and identical preparation setting up from 'ibādah to glorious motivation forum and celebration. Among others was $\mathrm{KBIH}$ Al Barokah, Yogyakarta. Since Al Barokah was also a pesantren based-agency, many devoted jamáa also become pilgrims for umrah. It was also form a limited group of $j a m a a^{\prime} a{ }^{32}$ making a trip to Haramain every two or three years annually. $\mathrm{KBIH} \mathrm{Al}$ Barokah provides them with mujāhadah (series of prayer and chanting led by the kyai, added with special prayer for the jama'a on the successful for umrah). The mujāhadah was done every selapan (Javanese system of calendar, equal to a month of period or 36 days). During mujāhadah and the trip of umrah jama'a were led and guided (mutawwif) by KH. Fatih Rosim and his wife Hj. Rosita. They both brought the customers to the sacred sites, such as Hijr Ismail, in front of the Ka'abah, also in Multazam. Kyai Rosim will recite special wirid and prayer for worshipers' successfulness in their business and life. During the voyage, santri of $\mathrm{Al} \mathrm{Barokah}$ and the relatives of the pilgrims will support their spiritual tourism by mujāhadah. ${ }^{33}$

A very special religious conduct done by $\mathrm{KBIH}$ Al Barokah was typical for $\mathrm{KBIH}$ as well as Travel agencies who based their services for more spiritual and religious need. In line to this activity, Wisata Hati Travel, Semarang majoring their services for counseling the pilgrims' needs. They see the complexity of Muslims' anxiety to perform umrah, either caused by overpriced necessitate of umrah or impious concern. For that, Wisata Hati

school preferred to say that umrah is fardhu kifayah (obligatory in group) rituals in Islam.

${ }^{32}$ It is stated that the group of jama'a consists of vegetables and fruits trader from a prominent green market in Jogjakarta. The jama' $a$ affords the capital by saving money regularly to $\mathrm{KBIH} \mathrm{Al} \mathrm{Barokah} \mathrm{for} \mathrm{the} \mathrm{period} \mathrm{of} \mathrm{two} \mathrm{or} \mathrm{three} \mathrm{years.}$ So the mujāhadah was kind of mental as well as spiritual motivation for them to gain their need to perform Umrah in the last of that period. Interview with Rimaya Ahadia, Marketing te am of KBIHAl Barokah, January 20, 2016. 10:23 am.

${ }^{33}$ Interview with Rimaya Ahadia, Marketing team of $\mathrm{KBIH}$ Al Barokah, January 20, 2016. 
initiated a series of counseling forum as well as motivation based on rituals. This activity is called riya $\overline{d a h}$. This ritual is organized to review the motivation and the purposes of umrah and hajj. At the end of every session (the ritual held in every Saturday and Sunday), Wisata Hati runs a discussion to talk about the jama'a's problems, aimed for counseling to assure their belief of coming into Ka'ba. As part of counseling, Wisata Hati convinces the customers with continuous yelling a phrase "Allah dulu, Allah lagi, Allah seterusnya" (God first, God Again, God Continues).

Since Muslims' ability to perform umrah and hajj (pilgrimage) in Islam has been perceived, religiously, as a matter of God's preference, the counseling through riyā optimistic feeling that all Muslims are, indeed, given the opportunity to travel to and visit Bayt Allāh. On the other hand during riyadha, this travel agent attempted to guide the jama' $a$ on a series of rituals. First, riyadha is a part of Sufi tradition benefited for individual training that particularly functions as selfcontrolling. In this regular practice, they may gradually fight against any kind of hunger, maintain a sincere soul, mind, emotions, as well as body. Second, these series of spiritual activities will help jama'a to get used to stimulating their daily life in accordance with the Qur'anic morality and Sunna.

Apart from that of rituals, Wisata Hati also stimulated jama'a to comprehensively intensify their ibadah in order to gain a multiple pahala (ajrun, reward from God) by following Allah's ways. The spirit of coming to Bayt Allāh may be risen from active caring for others during the time of asking Allah's grace to visit Bayt Allāh. By loving others, Wisata Hati inspired jama'a to show up a kind-hearted emotion through charity during riyādah meeting. Also the agency came up with many prominent figures (such as the supervisor of the agency, Ustadz Yusuf Mansur), as well as watching any kind of film that portrayed a struggle for visiting Bayt Allāh. It is, then, unsurprising to find jama'a Wisata Hati who perceived their travelling to Bayt Allāh as a kind of miracle, since the series of motivation has magnificently influenced their mood and emotion. ${ }^{34}$

${ }^{34}$ Arum, "Implementasi Actua ting," 37-38. 
Unlike the pilgrims of $\mathrm{KBIH} \mathrm{Al}$ Barokah that proceeded umrah by merely chanting and remembering God (wirid) during the mujāhadah, Wisata Hati that successfully modified the worship with more rationale effort; Al Azhar travel agency practiced different approach to attract the jama'as' attention. It is begin with the attention that the primary ritual of umrah lies in the journey itself, through series of praying at spiritual sites during the journey. Muhammad Syahrul, the mutawwif and the owner of agency, refused to see umrah as part of tourism, yet it is a ziyāra, series of rite the passage during the journey. Unlike other four primary rituals in Islam, ${ }^{35}$ hajj (as well as umrah) is a comprehensive ritual, demanding for both spiritual and material ability of Muslims. However, their possibility as well as ability to perform umrah is related ultimately to Allah's grace and award. So, one may see a rich Muslim, or a pious one but he/she cannot afford for umrah? On the other hand, one may also witness an elder, poor and the sick; but they made a visit to Mecca. So those who are able to visit Mecca and Medina are the chosen Muslims, and the ritual, during the journey should be performed totally in order to effectively utilize their time during the visit.

Muhammad Syahrul, who often accompanied the jama'a continuously encouraged his jama'a to focus on their $i b \bar{a} d a h$ during every site-visit:

"it Started from the Sunna to first take a special shower, there we invite jama'a to explicate the words of the Prophet Muhammad pbuh: "Wash you and then tie a bandage on the attire of ihrom!". Then we invite pilgrims to perform their prayers in the mosque, and then read talbiyah in a loud voice, it has to be in a loud voice, so they may infiltrate the very spirit of this ziyārah (journey). Then we follow a verse "Wa al-takhadhū min maqām Ibrāhīm musalla $\bar{a}$ to perform shalat in front of the site. At each of these places we then tell the stories of the prophets, put more attention to the teachings, then glorify Allah for making those history and hikmah (learning points) through our shalat. To some extent, we recite prayer, du'a, and sometimes say in Bahasa Indonesia, so the pilgrims may intensively live with it. That was the things we go through with the other sites, such as Safä and Marwah, Hijr Ismā'îl, Rawḍah, and so forth. Especially at times we lead jama'a to Ka'aba, we call them to -as they could- face to the Kaaba, during the

${ }^{35}$ Five pillar of Islam (rukn al-Islam) consist of Shahadat (confession of oneness of God and Muhammad is His Mesenger), salah (daily prayer), zakah (alms giving), fasting during Ramadhan), and hajj 
chanting and reciting of the prayer, we encourage to live the struggle of the Prophet Muhammad as well as to reflect on our lives now. In that way, crying is a matter of voluntary emotion we ever found." 36

Thus, in every trip he made, worship is the very basic intention, as well as to practice tradition. Syahrul motivated the jama'a on every ziyāra of $\mathrm{Al}$ Azhar to avoid shopping activity, and put their emphasis on the ziyāra to various sites out site Ka'ba and Nabawi Mosque, in Bayt Allāh.

\section{Umrah as promotion for Sunna and Tourism}

In today's global era, umrah has become a commodity of tourism industry (tourism). As commodity, umrah enters into advertisement spaces and is sold travelers as a product. Umrah travel agents show and prove that the umrah is a need for every Muslim. Understood from the perspective of popular culture like this, umrah is a global trend that is currently no longer showed only the highest spiritual symbols of worship in Islam but also a symbol of lifestyle (life style) of middle-class Muslim community in Indonesia. ${ }^{37}$

But on the other hand spiritual tourism can also be seen as a way of how religion can survive even in the era of secular consumerism today. Because as part of spiritual tourism, umrah plays an important role to increase the motivation of pilgrims in improving worship and their spirituality in every aspect of life, even with their intention to have vacation. These are perceived by the travel agency as the organizer of umrah as a business opportunity. This is where the needs of pilgrims and organizers perception on sunna will meet as mutual understanding. Knowledge of the Sunna as a body of knowledge is not only experiencing transmission but also transformed into a program that is packed with a variety of models. This is called by Haq as

${ }^{36}$ From the interviews conducted, the authors get as mutawwif reference that he took the Prophet Hajj refe rence about the story from sources, such as the Figh al-Sunna of Sayyid Sabiq (Al-Fath Lil I'lam Al-Arabi, tt), Sirah Nabawiyyah by Ibn Hisyam, etc. About Prayer Ritual, beside all of these references, M. Syahrul also cites from Book of Manasik by Religion Departement of Indonesia.

${ }^{37}$ Sucipto, “Umrah sebagai Gaya,” 29. 
intangible service and immaterial nature of the organizers of spiritual tourism.

Transmission process in the service process of umrah occurred in terms of what is known as the sunna, and how umrah as one sunna is perceived in this context. Thus, the sunna in this practice can be classified as sunna as understood by jurists, where sunna is interpreted as everything set by the Prophet outside of the category of obligatory and compulsory. Although sunna is close in meaning to jurisprudence, but in practice the jurisprudence that travel agencies point out are also quite diverse. For example, there are certain agencies that emphasize umrah once in every pilgrimage to the holy land. However, others motivate customers to perform umrah as many as they can do. Of course this does not include some of the prayers invoked by mutawwif and umrah pilgrims in various sacred sites in the Holy Land. This last fact proves that even a Sunna as understood from the standpoint of Islamic jurisprudence that are rigid and stiff, when viewed more broadly indicates precisely the nature sunna nor obligatory, which is flexible and has a wide variety of expression. Then this fact shows that for Muslims (especially in the practice of umrah) sunna is information about what was said, done, or approved by the Holy Prophet as well as about the companions, and the early generations of Islam.

"In other words, the Sunna is the concept of behavior, both of which apply to acts of physical or mental actions, both occurring once and recurrent." 38

Each of the Travel Bureau observed showed their mission to carry out a sunna, but the emphasis of the respective travel agency strongly associated with social and theological problems faced by pilgrims. Al Azhar Travel Bureau, Solo, for example, emphasizes democratic side of Islamic law that avoids discrepancy opinion (khiläfiyyah) although in terms of permissible thought. $\mathrm{KBIH}$ ASBIHUNU emphasizing instead embedded mission of jurisprudence and theology schools of ahl sunna wal jama'a as a school of thought that has long been followed by Muslims in Indonesia. While Heart Travel Bureau in Semarang and Zafira

${ }^{38}$ Fazlur Rahman, Membuka Pintu Ijtihad, trans. Anas Mahyudin (Bandung: Pustaka, 1965), 1-2. 
Travel Bureau in Yogyakarta give more thought to the uncertainty of the pilgrims, it emphasizes the vision of preaching Islam which put greater emphasis on the belief in the law of God and the Sunna of the Prophet, and to plan for their future optimism. The mission of the various travel agencies and KBIH shows their emphasis on what is referred to as sunna in Islam.

Another interesting practice to be explored from umrah as spiritual tourism is the commercial aspect of services given during pre-departure, departure and arrival. Although these services are the practice of worship that includes umrah, in fact these are all part of travel services provided by $\mathrm{KBIH}$ and travel agencies to satisfy their customers. The travel agency also gives a short handbook of umrah and its spiritual beneficiaries. In the customer's eyes, these are seen as a serious effort that makes the spiritual journey acceptable (mabrur).

Although resembling travels in general, pilgrim is a unique tour. It makes an investment that cannot be determined by the value of the return (investment with no tangible rate of return). It also determines the decisions that are prepared regularly/ constantly. Moreover, pilgrim takes on a special occasion and time that require the pilgrim traveler to have a spiritual and mental preparation (riya $\bar{a} d a h)$, as this is performed by pilgrims of Heart Travel Semarang and through intensive moral-spiritual preparation and prayer (mujāhadah) by pilgrims of KBIH Al Barokah, Yogyakarta. As explained above, Heart Travel that claims itself as a religious counselor emphasizes on the prolonged investment of the umrah. Various programs in riya ạ lah like alms and motivation are included as part of the travel during the pre-departure process. Likewise, series of chanting God's name (dhikr) and manākib reading are circulated in $\mathrm{Al}$ Barokah travel agency. These are considered as spiritual investment. 


\section{References}

Arum, Yestik. "Implementasi Actuating dalam Program Riyadhah Umroh dan Haji di Wisata Hati Semarang Tahun 2011." Undergraduate Thesis, IAIN Walisongo, 2013.

Asbihu NU. "Profile Asosiasi Bina Haji dan Umrah Nahdlatul Ulama (ASBIHU-NU)," n.d. Accessed January 9, 2017. http://wisatahaji.com/profil-asbihu-nu/.

Battour, Mohamed, Mohd Nazari Ismail, Moustafa Battor, and Muhammad Awais. "Islamic Tourism: An Empirical Examination of Travel Motivation and Satisfaction in Malaysia." Current Issues in Tourism 20, no. 1 (January 2, 2017): 50-67.

van Bruinessen, Martin. “Mencari Ilmu dan Pahala di Tanah Suci: Orang Nusantara Naik Haji (Seeking Knowledge and Merit: Indonesians on the Hajj)." Jurnal Ulumul Qur'an 2, no. 5 (1990): 42-49.

Buitelaar, Marjo. "Mecca as the Centre of Globalization: The Hajj Today." In Hajj: Global Interractions Trough Pilgrimage, by Luitgard Mals and Marjo Buitelaar. Leiden: Sidestone Press, 2015.

Bulliet, Richard. Islam the View from the Edge. New York: Columbia University Press, 1994.

Dhofier, Zamakhsyari. "Dampak Ekonomi Haji di Indonesia." Prisma XIII, no. 4 (April 1984).

Duderija, Adis. "Evolution on the Concept of Sunna during the First Four Generations of Muslims in Relation to the Development of the Concept of an Authentic Hadith as Based on Recent Western Scholarship." Journal of Arab Law Quarterly 26, no. 4 (January 2012):393-437.

Fealy, Greg, and Sally White. "Mengonsumsi Islam: Agama yang Dijadikan Jualan dan Kesalehan yang Diidam-idamkan di Indonesia." In Ustadz Seleb Bisnis Moral dan Fatwa Online; Ragam Ekspresi Islam Indonesia Kontemporer, translated from Expressing Islam: Religious Life and Politics in Indonesia. Jakarta: Komunitas Bambu, 2012.

Guraya, M. "The Concept of Sunna in the Muwatta of Malik Bin Anas.” Ph.D. Dissertation, McGill University, 2015. 
- - - "The Concept of Sunna in the Muwatta of Malik Bin Anas." In The Concept of Sunna and Its Status in Islamic Law, edited by M. Guraya. New York: Palgrave, 2015.

Haq, Farooq, Anita Medhekar, and Phil Bretherton. "Public and Private Partnership Approach for Applying The Tourism Marketing Mix to Spiritual Tourism." In Academic Conference on Intellectual Perspectives \& Multi-Disciplinary Foundations, edited by David King. Vol. 8. Las Vegas, NV, USA, 2009.

Haq, Farooq, and Ho Yin Wong. "Is Spiritual Tourism a New Strategy for Marketing Islam?" Journal of Islamic Marketing 1, no. 2 (2010): 136-148.

al-Harmaneh, Ala. "New Tourism Trends in Arab World." Islamic Tourism, no. 16 (April 2005).

Hassan, Siti Hasnah, Siti Rohaida Mohamed Zainal, and Osman Mohamed. "Determinants of Destination Knowledge Acquisition in Religious Tourism: Perspective of Umrah Travelers." International Journal of Marketing Studies 7, no. 3 (May 31, 2015): 84-94.

Lindsey, Tim. "Monopolising Islam: The Indonesian Ulama Council and the State Regulation of "the Islamic Economy.'" Bulletin of Indonesian Islamic Studies 48, no. 2 (2012): 253-274.

Lutfi, Mukhtar. "Ijtihad Fazlur Rahman." Al-Fikr 16, no. 2 (2012): 27-40.

Mustafayeva, A. A., G. E. Nadirova, Sh. S. Kaliyeva, and B. Zh. Aktaulova. "Developing Islamic Tourism in Kazakhstan: A Result of a Religious Revival or a New Trend of Tourism." World Academy of Science, Engineering and Technology International Journal of Social, Behavioral, Educational, Economic, Business and Industrial Engineering 6, no. 11 (2012): 3277-3279.

Olsen, Daniel H., and Dallen J. Timothy. Tourism, Religion and Spiritual Journeys, . London: Routledge, 2006.

Rahman, Fazlur. Membuka Pintu Ijtihad. Translated by Anas Mahyudin. Bandung: Pustaka, 1965.

- - - "Sunna and Hadith." Journal Islamic Studies, Islamic Research Institute, International Islamic University, Islamabad 1, no. 2 (June 1962): 1-36. 
Soehadha, Moh. "Citra Haji dalam Konstruksi Media." In Cultural

Studies di PTAI Teori dan Praktik, 1:158-174. Bunga Rampai. Yogyakarta: Label, 2015.

Sucipto. “Umrah sebagai Gaya Hidup, Eksistensi Diri dan Komoditas Industri: Menyaksikan Perubahan Keagamaan Warga Kota." Jurnal Kontekstualita 28, no. 1 (2013): 15-33.

Suryadi, and M. Mansur et al. "Dari Living Sunna ke Living Hadis." In Metodologi Penelitian Living Qur'an dan Hadis. Yogyakarta: TH Press, and Teras, 2007.

Tagliacozzo, Eric, and M. Toorawa Toorawa, eds. The Hajj: Pligrimage in Islam. New York: Cambridge University Press, 2016.

"Bimbingan Manasik Haji." Departemen Agama Republik Indonesia, 2003.

"Keputusan Menteri Agama RI Nomor 210 Tahun 2016 Tentang Penetapan Kuota Haji Tahun 1437 H / 2016 M," May 10, 2016. https://haji.kemenag.go.id/v3/content/keputusan-menteriagama-ri-nomor-210-tahun-2016-tentang-penetapan-kuotahaji-tahun. 